Ife Journal of Science vol. 20, no. 3 (2018)

\title{
EVALUATION OF ANTI-INFLAMMATORY AND GENOTOXICITY POTENTIALS OF THE FRACTIONS OF ARCHIDIUM OHIOENSE (SCHIMP. EX MULL) EXTRACT
}

\author{
Akinpelu, B. A. ${ }^{1 *}$, Godwin, A ${ }^{1}$, Aderogba M. A ${ }^{2}$., Makinde A. M. ${ }^{3}$, Azeez S. O. ${ }^{3}$, Oziegbe M. ${ }^{3}$ \\ Department of Biochemistry, Obafemi Awolowo University, Ile-Ife, Nigeria \\ ${ }^{2}$ Department of Chemistry, Obafemi Awolowo University, Ile-Ife, Nigeria. \\ ${ }^{3}$ Departments of Botany, Obafemi Awolowo University, Ile-Ife, Nigeria. \\ *Corresponding author's e-mail: baakinpelu@gmail.com \\ (Received: $18^{\text {th }}$ June, 2018; Accepted: $18^{\text {th }}$ July, 2018)
}

\section{ABSTRACT}

\begin{abstract}
This study evaluated red blood cell (rbc) membrane stabilization and albumin denaturation, xanthine oxidase and lipoxygenase inhibitory activities of $\mathrm{n}$-hexane (Hex), dichloromethane (DCM), ethyl acetate (EtOAc), butanol $(\mathrm{BuOH})$ and aqueous $(\mathrm{Aq})$ fractions of Archidium obioense methanolic extract using standard procedures. Diclofenac was used as a positive control for both rbc membrane stabilization and albumin denaturation studies while allopurinol and ascorbic acid respectively were used as positive control for xanthine oxidase and lipoxygenase inhibition measurements. Furthermore, genotoxic effect of the two most active fractions of the extract (EtOAc and DCM) on Allium cepa meristematic cells was investigated. Results showed that all the fractions inhibited heat-induced bovine serum albumin denaturation activity with the EtOAc and DCM fractions exhibiting better inhibitory activity than other fractions. Also, all the fractions except aqueous fraction compared favourably with the diclofenac (maximum stability of $86.94 \pm 0.00 \%$ ) and protected stressed erythrocyte membrane at various concentrations tested. The maximum percentage erythrocyte stabilities were $97.39 \pm 0.00,96.23 \pm 0.00,91.85 \pm 0.00, \quad 87.71 \pm 0.00$ and $23.93 \pm 0.01 \%$ for A. obioense EtOAc, DCM, n-Hex, $\mathrm{BuOH}$ and $\mathrm{Aq}$ fractions, respectively. It was observed that EtOAc fraction, DCM fraction and ascorbic acid inhibited lipoxygenase activity by $70.00 \pm 2.36,75.00 \pm 1.67$, and $62.50 \pm 8.84 \%$ respectively while $71.67 \pm 3.54$, $50.00 \pm 0.00$ and $77.50 \pm 1.76 \%$ of xanthine oxidase inhibition were elicited by EtOAc fraction, DCM fraction and allopurinol respectively. EtOAc and DCM fractions showed significant reduction in mitotic index and root lengths of Allium cepa at higher concentrations. Also, sticky chromosomes were observed for EtOAc (300 $\mu \mathrm{g} / \mathrm{ml})$ and DCM $(300-350 \mu \mathrm{g} / \mathrm{ml})$ fractions. It was concluded that $A$. obioense plant possesses antiinflammatory potential with the EtOAc and DCM fractions demonstrating very strong anti-inflammatory activity and compare favourably with standard reference drug (diclofenac). However, these fractions inhibited cell division of $A$. cepa cells at higher concentration.
\end{abstract}

Keywords: Archidium obioense, Lipoxygenase, Xanthine oxidase, Allium cepa, Genotoxicity, Mitotic index

\section{INTRODUCTION}

Inflammation is a response process used by the cells to fight injurious agents (Jaykumar et al., 2012). The causes may include infection, noxious chemicals and drugs, stress, UV exposure, etc, (Iwalewa et al., 2007). Once tissue is damaged, cells respond against such damage by releasing inflammatory mediators such as serotonin, histamine, cytokines and chemokines, in order to combat further damages (Iwalewa et al., 2007) and restore healing. The damage may trigger the release of membrane phospholipids which are catalyzed by phospholipases to release arachidonic acids.

The lipases are inhibited by corticosteroids though; the precise mechanisms are still conjectural. Following release, arachidonic acid is rapidly metabolized by four separate pathways: the cyclooxygenase (COX), lipoxygenase (LOX), P450 epoxygenase, and isoprostane pathways. The type of eicosanoid produced depends on the cell type, cell's phenotype, mode of cell stimulation and nature of the fatty acid esterified in the membrane phospholipids (Bertram, 2004).

The two isoforms of cyclooxygenase (COX 1 and COX 2) metabolize arachidonic acid to prostaglandins. COX 1 is constitutively expressed and responsible for housekeeping function while COX 2 is inducible (Gupta and DuBois, 2001).

The three isoforms of lipoxygenase (5-LOX, 12LOX, and 15-LOX) metabolize arachidonic acid, to leukotrienes (Gupta and DuBois, 2001) which are associated with asthma and anaphylactic shock. The two major goals set in the treatment of 
inflammation are to relief pain and slow or arrest the tissue-damaging process. Both non-steroidal anti-inflammatory drugs (NSAIDs) and steroidal anti-inflammatory drugs (SAIDs) are used in the treatment of inflammation. However, it was reported that they both produce harmful effects such as gastric irritation, nephrotoxicity and hepatotoxicity. There is therefore need to search for effective and safe anti-inflammatory compounds from nature (Jaykumar et al., 2012).

Certain mosses have been reported to possess anti-inflammatory, antioxidant, antibiotic and antitumor properties (Paudel et al. 2014; Savaroğlu et al., 2011).

In continuation of our previous studies on antiinflammatory activity of the crude extracts of $A$ obioense using solvents of different polarities (Akinpelu et al., 2015), we report the antiinflammatory activities of fractions obtained from the methanolic crude extract of the plant. Also, genotoxic effect of the potent fractions on mitotic cells in Allium cepa root tips was evaluated.

\section{MATERIALS AND METHODS}

\section{Materials \\ Plant Collection}

The plant material was collected from Obafemi Awolowo University Ile-Ife campus, and authenticated at IFE Herbarium, Department of Botany, of the same University with the voucher specimen (IFE-17406) number.

\section{Methods}

\section{Preparation of Crude Extract}

The dried powdered material $(1.5 \mathrm{~kg})$ was soaked with $80 \%(\mathrm{v} / \mathrm{v})$ methanol for $48 \mathrm{~h}$ and filtered. The residue was further soaked with $80 \%(\mathrm{v} / \mathrm{v})$ methanol for another $48 \mathrm{~h}$. The filtrate was pooled and concentrated in vacuo at $35^{\circ} \mathrm{C}$ to obtain the crude extract.

\section{Solvent Partitioning of Crude Extract}

The crude extract $(2.0 \mathrm{~g})$ was suspended in distilled water and successively partitioned with $\mathrm{n}$ hexane (200 $\mathrm{ml} \times 4)$, dichloromethane $(200 \mathrm{ml} \mathrm{x} 4)$, ethyl acetate $(200 \mathrm{ml} \times 4)$ and n-butanol (200 $\mathrm{ml} \mathrm{x}$ 4). Each solvent fraction was separately concentrated to dryness in vacuo to obtain a total of five fractions (Godwin et al., 2015).

\section{Phytochemical Screening}

Each fraction was screened for the presence of secondary metabolites as described by Trease and Evans (2002) and Sofowora (2006).

\section{Membrane Stabilizing Assay}

The assay was based on the modified procedure of Oyedapo et al. (2010). Briefly, the mixture contained $1.0 \mathrm{ml}$ of hyposaline, $0.5 \mathrm{ml}$ of phosphate buffer (0.15 M, pH 7.4), varying concentrations of each fraction $(0-350 \mu \mathrm{g} / \mathrm{ml})$ which was made up to $3.0 \mathrm{ml}$ with normal saline and $0.5 \mathrm{ml}$ of $2 \%(\mathrm{v} / \mathrm{v})$ erythrocytes. The reaction mixture was incubated at $56{ }^{\circ} \mathrm{C}$ for $30 \mathrm{~min}$ and centrifuged at $3000 \mathrm{rpm}$ for $10 \mathrm{~min}$. The absorbance of the supernatant was read at $560 \mathrm{~nm}$ against reagent blank. The percentage membrane stability was calculated from the equation:

$\%$ Membrane Stability $=$ $\left.-\frac{\text { Absorbance }_{\text {test drug }}-\text { Absorbance }_{\text {drug control }}}{\text { Absorbanceblood control }} \times 100\right)$

\section{Protein Denaturation Inhibitory Assay}

The modified procedure of Mizushima and Kobayashi (1968) as reported by Aina and Oyedapo (2013) was adopted. The reaction mixture contained $0.5 \mathrm{ml}(0.25 \mathrm{mg} / \mathrm{ml} \mathrm{BSA})$ and varying concentrations of each fraction (0-350 $\mu \mathrm{g} / \mathrm{ml}$ ) to a volume of $3.0 \mathrm{ml}$ and incubated at $37 \pm 2{ }^{\circ} \mathrm{C}$ for $20 \mathrm{~min}$. The reaction mixture was heated at $57 \pm 2{ }^{\circ} \mathrm{C}$ for $3 \mathrm{~min}$ followed by addition of $2.5 \mathrm{ml}$ phosphate buffer $(0.5 \mathrm{M}, \mathrm{pH}$ 6.3). From each reaction mixture, $1 \mathrm{ml}$ was pipetted into fresh test tube followed by addition of copper-alkaline reagent $(1 \mathrm{ml})$ and $1.0 \mathrm{ml}$ of Folin-CiocateuPhenol reagent (1:10). The reaction mixture was then incubated at $55^{\circ} \mathrm{C}$ for $10 \mathrm{~min}$. The tubes were allowed to cool and absorbance was measured at $650 \mathrm{~nm}$ against reagent blank. The quantity of undenatured protein left and \% inhibition were calculated from the equation:

Total Protein $=\frac{\text { Absorbance }_{\text {sampls at } 650 \mathrm{~nm} X \text { concentration }_{\text {standerd }}}}{\text { Absorbance }_{\text {standard }} \text { at } 650 \mathrm{~nm}}$

Undenatured Protein Left $=$

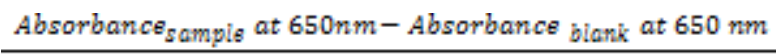
Absorbance $_{\text {standard }}$ at $650 \mathrm{~nm}-$ Absorbance blank $_{\text {bi }}$ at $650 \mathrm{~nm}$ 
$\%$ Inhibition $=\frac{\text { Protein left }}{\text { Total Protein }} \times 100$

\section{Xanthine Oxidase Inhibitory Assay}

The in vitro xanthine oxidase inhibition potential of EtOAc and DCM fractions was carried out according to the modified procedure of FerrazFilha et al. (2006) as reported by Konate et al. (2011). Each fraction was directly dissolved in phosphate buffer-MeOH (1\%) and screened for xanthine oxidase inhibitory activity at final concentration of $50 \mu \mathrm{g} / \mathrm{ml}$. The assay mixture consisted of $150 \mu \mathrm{l}$ phosphate buffer $(1 / 15 \mathrm{M}, \mathrm{pH}$ 7.5), $50 \mu \mathrm{l}$ solution of each fraction and $50 \mu \mathrm{l}$ enzyme solution $(0.28 \mathrm{U} / \mathrm{ml}$ in phosphate buffer). The reaction was initiated by adding $250 \mu$ of 0.15 $\mathrm{mM}$ substrate solution (dissolved in water). Change in absorbance was recorded at $295 \mathrm{~nm}$ for 2 min. Negative control was prepared and contained $1 \%$ methanol solution without the extract. Allopurinol a well-known inhibitor of xanthine oxidase was used as positive control at a final concentration of $50 \mu \mathrm{g} / \mathrm{ml}$. Percentage xanthine oxidase inhibitory activity was expressed using the equation:

$\%$ Inhibition $\left.=\frac{1-B}{A}\right) \times 100$

$A=$ change in absorbance of the assay without the fraction

$\mathrm{B}=$ change in absorbance of the assay with the fraction

\section{Lipoxygenase Inhibitory Assay}

Lipoxygenase inhibitory activity of the EtOAc and DCM fractions with linolenic acid as substrate was measured as described by Ferraz-Filha et al. (2006) as reported by Konate et al (2011). EtOAc and DCM fractions were separately dissolved in phosphate buffer and screened for lipoxygenase inhibitory activity at final concentration of 50 $\mu \mathrm{g} / \mathrm{ml}$. The assay mixture consisted of $150 \mu \mathrm{l}$ phosphate buffer (1/15 M, pH 7.5), $50 \mu \mathrm{l}$ solution of fractions and $50 \mu \mathrm{l}$ enzyme solution $(0.28 \mathrm{U} / \mathrm{ml}$ in phosphate buffer). The reaction was initiated by adding $250 \mu \mathrm{l}$ of $0.15 \mathrm{mM}$ substrate solution (dissolved in water). Change in absorbance was recorded at $234 \mathrm{~nm}$ for $2 \mathrm{~min}$. Negative control was prepared and contained 1\% methanol solution without extract solution. Ascorbic acid, ed well-known inhibitor of lipoxygenase was used action) and phenolics (Table 1). a positive control at a final concentration of 50 $\mu \mathrm{g} / \mathrm{ml}$. The experiments were performed in triplicate. Lipoxygenase inhibitory activity was expressed as the percentage inhibition of lipoxygenase, calculated as (\%) inhibition following equation:

$\%$ Inhibition $\left.=\frac{1-B}{A}\right) \times 100$

$A=$ change in absorbance of the assay without the fraction

$\mathrm{B}=$ change in absorbance of the assay with the fraction

\section{Root Growth Inhibition Assay: Allium cepa Model}

Fresh onion bulbs (20) were purchased and sundried for two weeks. The bottom plates were scraped and seated in distilled water to initiate rooting for $24 \mathrm{~h}$. The best rooted 15 bulbs were selected and used for the study (Rank and Nielson, 1993). The bulbs were planted separately in 0,100 , 200,300 and $350 \mu \mathrm{g} / \mathrm{ml}$ of the EtOAc and DCM fractions for $72 \mathrm{~h}$ and distilled water served as control. Thereafter, the roots were harvested and fixed in acetic acid/ethanol $(1: 3 \mathrm{v} / \mathrm{v})$ for $24 \mathrm{~h}$ and later stored at $4{ }^{\circ} \mathrm{C}$. The lengths of five roots from each bulb were measured and the mean root length was calculated. The percentage root growth inhibition (Farhad et al., 2011) was calculated as:

$\%$ Growth $=\left(1-\frac{\text { Sample }}{\text { Control }}\right) \times 100$

\section{Assay of Genotoxicity Activity in Allium cepa}

The fixed root $\left(\right.$ at $4{ }^{\circ} \mathrm{C}$ ) were hydrolyzed in $\mathrm{HCl}$ $(18 \% \mathrm{v} / \mathrm{v})$ for $10 \mathrm{~min}$ at room temperature. The tips of the roots were then crushed on clean slides and stained with FLP-orcein for 15 min (Rank and Nielson, 1993). The slides were viewed under x 10 and $\mathrm{x} 40$ of light microscope. The total numbers of cells including the dividing cells were counted. Data were obtained from 25 microscopic fields. Mitotic index was calculated as:

Mitotic index $=\frac{\text { Number of dividing cells }}{\text { Total number of cells }} \times 100$

\section{RESULTS} The fractions revealed the presence of flavonoids,
diac glycosides, terpenes, steroids (except in $\mathrm{BuOH}$ 
Table 1: Phytochemical Constituents of Fractions of A. obioense

\begin{tabular}{lcccc}
\hline $\begin{array}{l}\text { Phytochemical } \\
\text { Constituents }\end{array}$ & DCM & EtOAc & BuOH & $\begin{array}{c}\text { Aqueous } \\
\text { Fraction }\end{array}$ \\
\hline Flavonoids & + & Fraction & Fraction & Fraction \\
Tannins & - & + & + & + \\
Alkaloids & - & - & - & + \\
Saponins & - & - & - & + \\
Cardiac glycosides & + & + & + & - \\
Triterpenes & + & + & + & + \\
Steroids & + & + & - & + \\
Phlobatannins & - & - & - & + \\
Phenolics & + & + & + & + \\
\hline
\end{tabular}

$(+)$ represents positive result, (-) represents negative result.

Membrane stabilization profiles of $A$. obioense fractions and diclofenac on bovine erythrocytes exposed to heat and hypotonic-induced lyses are shown in figure 1.

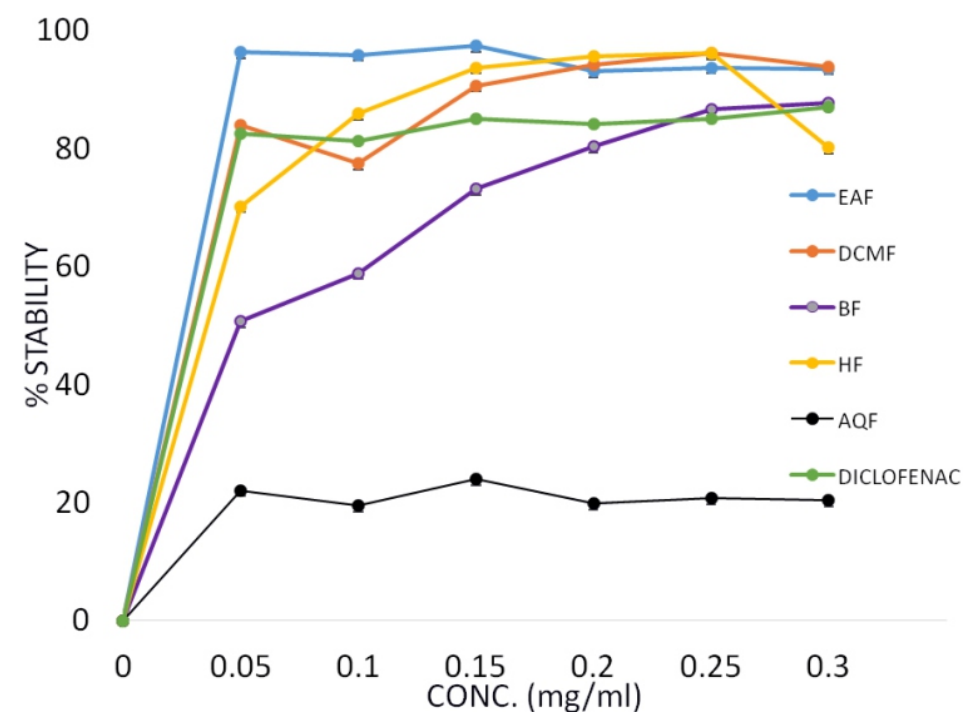

Figure 1: Membrane Stabilization Profiles of A. obioense Fractions on Stressed Bovine Erythrocytes.Each value represents the mean \pm SEM of 3 readings.

EAF: Ethylacetate fraction, DCMF: Dichloromethane fraction, BF: Butanol fraction, $\mathrm{HF}: \mathrm{n}-\mathrm{Hexane}$ fraction, AQF: Aqueous fraction.

The percentage inhibition of albumin denaturation is presented in figure 2 . 


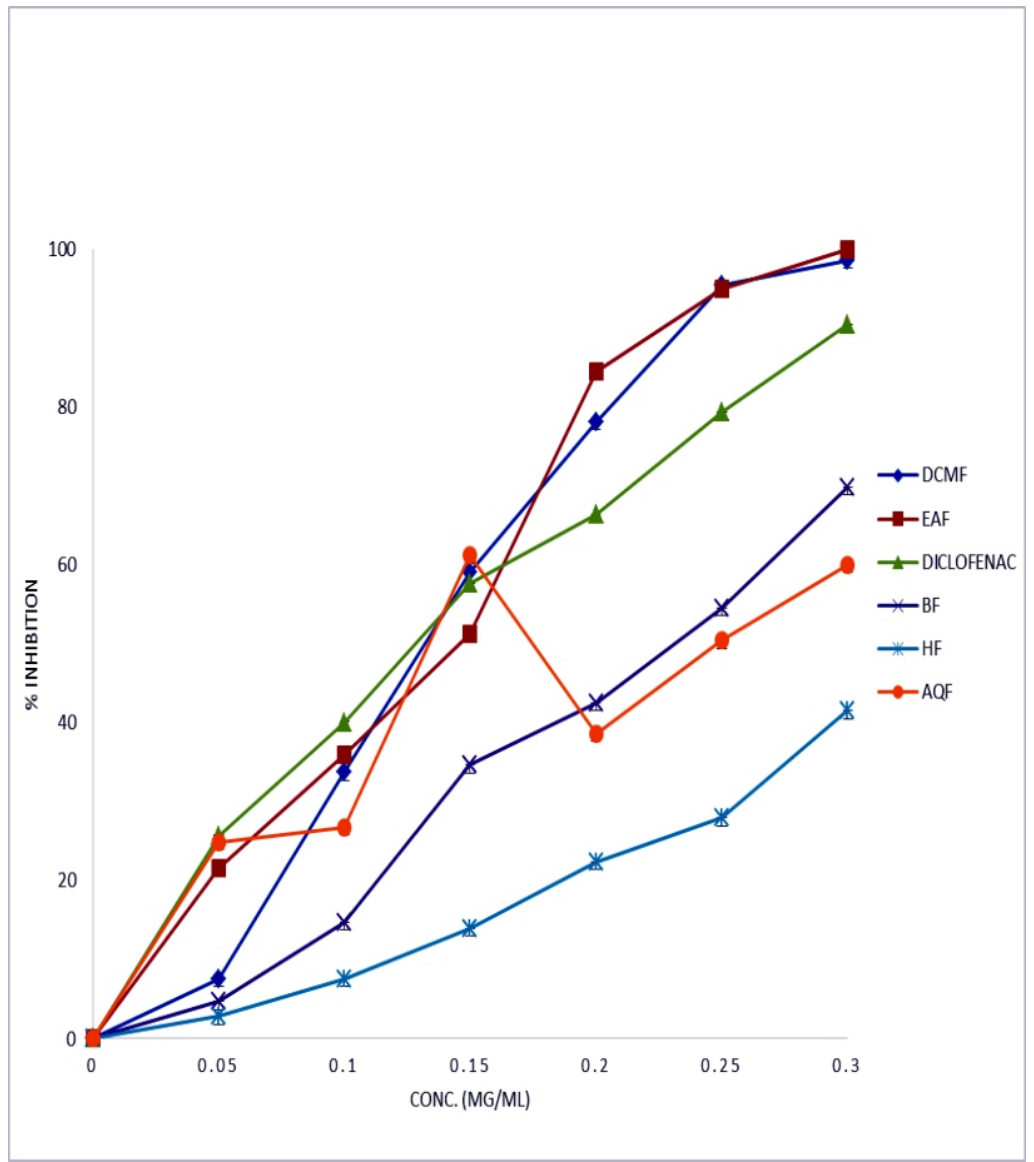

Figure 2: Effects of A. obioense Fractions on Bovine Serum Albumin Denaturation Inhibitory Activity.

Each value represented the mean \pm SEM of 3 readings.

EAF: Ethylacetate fraction, DCMF: Dichloromethane fraction, BF: Butanol fraction, HF: n-Hexane fraction, AQF: Aqueous fraction.

The percentage inhibitory activities of EtOAc and DCM fractions at $5 \mu \mathrm{g} / \mathrm{ml}$ on lipoxygenage and xanthine oxidase are as shown in table 2 . EtOAc fraction had highest $\%$ inhibitory activity compared to DCM fraction and allopurinol. EtAOc fraction was also observed to inhibit xanthine oxidase activity better than DCM fraction but both showed lesser inhibitory activity compared to Ascorbic acid (Table 2)

Table 2: Lipoxygenase and Xanthine Oxidase Percentage Inhibition Profiles of A. obioense EtOAc and DCM Fractions.

\begin{tabular}{lll}
\hline Fractions & $\begin{array}{l}\text { Lipoxygenase } \\
\text { Inhibition (\%) }\end{array}$ & $\begin{array}{l}\text { Xanthine oxidase } \\
\text { Inhibition (\%) }\end{array}$ \\
\hline DCM fraction & $71.66 \pm 3.53$ & $50.00 \pm 0.00$ \\
EtOAc fraction & $75.00 \pm 1.66$ & $62.50 \pm 8.83$ \\
Allopurinol & Not determined & $77.50 \pm 1.76$ \\
Ascorbic Acid & $70.00 \pm 2.35$ & Not determined \\
\hline
\end{tabular}

Tables 3 and 4 are a summary of concentrationdependent reduction in mitotic index of Allium cepa root tip meristem cells treated with different concentrations of $A$. obioense EtOAc and DCM fractions. Increase in the total number of non- dividing cells was observed as the fractions concentration increases compared to control hence mitotic index decreases as the EtOAc and DCM concentrations increase. 
Table 3: Effect of A. obioense EtOAc fraction on Mitotic Index of $A$. cepa Root.

\begin{tabular}{llllllll}
\hline $\begin{array}{l}\text { EtOAc } \\
\text { Fraction } \\
(\boldsymbol{\mu g} / \mathrm{ml})\end{array}$ & Prophase & Metaphase & Anaphase & Telophase & $\begin{array}{l}\text { Total } \\
\text { Dividing } \\
\text { Cells }\end{array}$ & $\begin{array}{l}\text { Total } \\
\text { Non- } \\
\text { Dividing } \\
\text { Cells }\end{array}$ & $\begin{array}{l}\text { Mitotic } \\
\text { Index }\end{array}$ \\
\hline $\mathbf{0}$ & & & & & & & \\
$\mathbf{1 0 0}$ & 55 & 30 & 06 & 03 & 94 & 1324 & 6.63 \\
$\mathbf{2 0 0}$ & 36 & 24 & 03 & 04 & 67 & 1556 & 4.13 \\
$\mathbf{3 0 0}$ & 46 & 23 & 13 & 12 & 93 & 1727 & 5.11 \\
$\mathbf{3 5 0}$ & 08 & 06 & 14 & 04 & 44 & 1347 & 3.16 \\
\hline
\end{tabular}

Table 4: Effect of $A$. obioense DCM fraction on Mitotic Index of $A$. cepa Root.

\begin{tabular}{llllllll}
\hline $\begin{array}{l}\text { DCM } \\
\begin{array}{l}\text { Fraction } \\
(\boldsymbol{\mu g} / \mathbf{m l})\end{array}\end{array}$ & Prophase & Metaphase & Anaphase & Telophase & $\begin{array}{l}\text { Total } \\
\text { Dividing } \\
\text { Cells }\end{array}$ & $\begin{array}{l}\text { Total } \\
\text { Non- } \\
\text { Dividing } \\
\text { Cells }\end{array}$ & $\begin{array}{l}\text { Mitotic } \\
\text { Index }\end{array}$ \\
\hline $\mathbf{0}$ & & & & & & & \\
$\mathbf{1 0 0}$ & 88 & 31 & 06 & 15 & 100 & 843 & 10.60 \\
$\mathbf{2 0 0}$ & 108 & 70 & 10 & 05 & 119 & 1289 & 8.45 \\
$\mathbf{3 0 0}$ & 199 & 11 & 02 & 24 & 234 & 2350 & 9.06 \\
$\mathbf{3 5 0}$ & 186 & 43 & 10 & 00 & 212 & 3230 & 6.16 \\
\hline
\end{tabular}

Microscopic analysis and stages of mitotic division and chromosomal aberrations caused by $A$. obioense EtOAc and DCM fractions are shown in plate 1 (B-E) compare to control (plate 1(A)

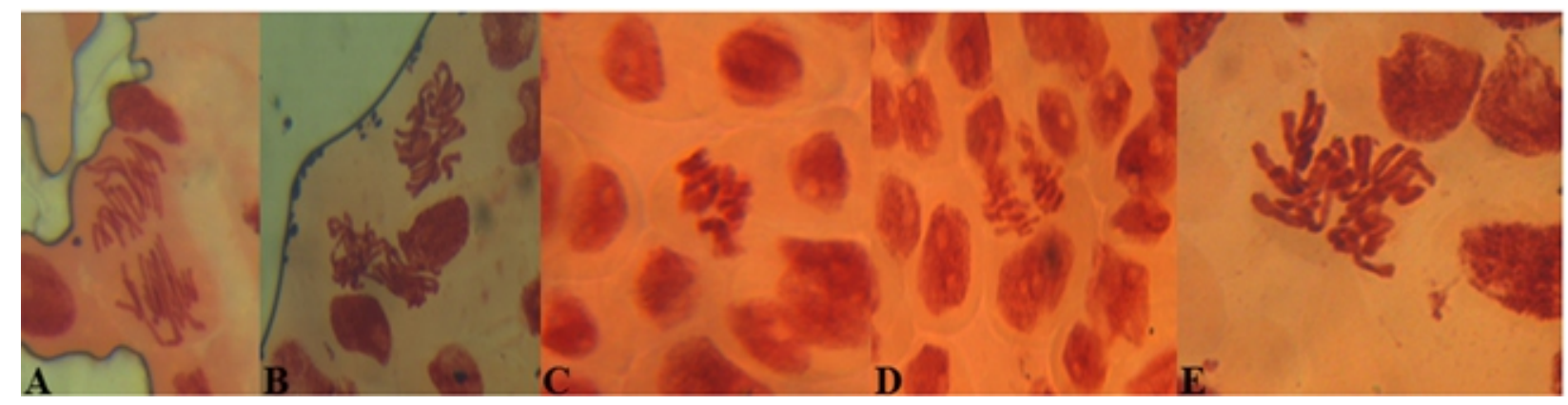

Plate 1 (A- E): Cell Division in Untreated and Treated Cells in Allium cepa assay

A-Normal anaphase in control (untreated)

B- Sticky metaphase at $350 \mu \mathrm{g} / \mathrm{ml}$ EtOAc fraction

C- Sticky metaphase at $300 \mu \mathrm{g} / \mathrm{ml}$ DCM fraction

D- Sticky anaphase at $300 \mu \mathrm{g} / \mathrm{ml} \mathrm{DCM} \mathrm{fraction}$

E- Sticky metaphase at $350 \mu \mathrm{g} / \mathrm{ml} \mathrm{EtOAc} \mathrm{fraction}$

\section{DISCUSSION}

The bioactivities of medicinal plants have been attributed to the presence of secondary metabolites. A. obioense tested positive for flavonoids, cardiac glycosides, terpenoids and phenolics in all the fractions. The presence of these metabolites contributes to the plant's medicinal functions (Edeoga and Eriata, 2001) and corroborated what had been reported in the literatures on medicinal activities of bryophytes extract constituents (Adedeji et al., 2012).

As shown in figure 1, all the fractions protected stressed erythrocytes and compared favourably with the reference anti-inflammatory drug (diclofenac). This finding corroborated Rupesh et al. (2013) investigation on in vitro anti-arthritic activity of Pongamia pinnata (Linn) Pierre and Punica granatum (Linn) in which $86.85 \%$ maximum percentage membrane stability was recorded for 
diclofenac.

Studies have revealed that flavonoids and saponins elicited strong and appreciable membrane stabilizing effect both in vivo and in vitro (Akinpelu et al., 2015; Oyedapo et al., 2010). In addition, flavonoids, monoterpenes and polyphenols were documented to exhibit antiinflammatory property (Bhattacharya, 2011). Therefore, the observed stabilization of stressed red blood cells by $A$. obioense could possibly be as a result of the presence of these phytochemicals.

Furthermore, the result of the protein denaturation inhibitory profile on heat-treated bovine serum albumin (Figure 2) showed that, the EtOAc fraction elicits highest percentage inhibitory capacity $(99.99 \pm 0.00 \%$ at $0.30 \mathrm{mg} / \mathrm{ml})$ followed by the DCM fraction $(98.00 \pm 0.01 \%$ at $0.30 \mathrm{mg} / \mathrm{ml}$ ) while $\mathrm{n}$-hexane fraction $(41.52 \pm 0.00 \%$ at $0.30 \mathrm{mg} / \mathrm{ml})$ was the least. The standard anti-inflammatory drug (diclofenac) had $90.40 \pm 0.02 \%$ inhibition at $0.30 \mathrm{mg} / \mathrm{ml}$.

Tissue protein denaturation has been implicated in inflammation. Also, production of autoantigens or self-antigens in certain arthritic conditions was reported to be attributed to the denaturation of tissue proteins in vivo (Vedpal et al., 2013; Umapathy et al., 2010). Denaturation and inflammation have similar physio-pathological phenomena and could be caused by heat, radiations, organic solvents, etc (Mizushima and Kobayashi, 1968). NSAIDs used in the management of inflammatory conditions have been reported in the protection of proteins against denaturation (Saso et al., 2001). Protein denaturation inhibitory capacity of $A$.ohiense plant observed in this study, supports antiinflammatory property of the plant.

In vitro lipoxygenase (LOX) and xanthine oxidase (XO) inhibitory activities of EtOAc and DCM fractions of $A$. obioense methanol extract were investigated based on their strong membrane stabilization and protein anti-denaturation activities compared to other fractions.

At $0.05 \mathrm{mg} / \mathrm{ml}$ EtOAc fraction inhibited LOX by $75.00 \pm 1.67 \%$ and $\mathrm{XO}$ by $62.50 \pm 8.84 \%$ while the DCM fraction, inhibited LOX by $71.67 \pm 3.54 \%$ and $\mathrm{XO}$ by $50.00 \pm 0.00 \%$. A standard reference drug, ascorbic acid exerts $70.00 \pm 2.36 \%$ LOX inhibitory activity while allopurinol inhibited XO by $77.50 \pm 1.77 \%$.

The activities of pro-inflammatory enzymes, lipoxygenase (LOX), xanthine oxidase (XO) and cyclooxygenase (COX), promote inflammation and other inflammatory-related disorders by furnishing pro-inflammatory mediators and free radicals (Bertram, 2004). COX and LOX are involved in the metabolism of arachidonic acids while $\mathrm{XO}$ is involved in the metabolism of purine nucleotides (i.e. hypoxanthine to xanthine) and generates $\mathrm{H}_{2} \mathrm{O}_{2}$, a reactive oxygen species. Therefore, inhibition of these enzymes is essential in the treatment of long term inflammatory disorder (Sweeney et al., 2001).

The sensitivity of LOX to EtOAc fraction might be attributed to reduction of $\mathrm{Fe}^{3+}$ to $\mathrm{Fe}^{2+}$ in the LOX structure (Samson et al., 2011). LOXs are highly sensitive to polyphenols. It converts arachidonic acid substrate or its isomer linolenic acid substrate into a $\mathrm{H}_{2} \mathrm{O}_{2}$ intermediate before final conversion into leukotriene product. Polyphenols block the formation of the intermediate by scavenging the lipid peroxyradicals in the peroxidation reaction (Bertram, 2004). The $\mathrm{H}_{2} \mathrm{O}_{2}$ intermediate is essential for the catalytic cycle of the LOX activity. The blockade of LOX activity by the polyphenols, results in the shortage of $\mathrm{H}_{2} \mathrm{O}_{2}$ intermediate hence, reduces the activity of the enzyme. Therefore, polyphenol content of the plant probably contribute to high inhibitory activity of LOX by A. obioense EtOAc fraction.

Gout and hyperuricemia are the common metabolic disorders in human affecting $1-2 \%$ of adults (Umamaheswari, 2009). The diseases are associated with an elevated level of uric acid in the blood leading to the deposition of urate crystals in the joints and kidneys. Presence of such crystals in the joints leads to gouty arthritis while the deposition of urate crystals in the kidneys leads to uric acid nephrolithiasis. Xanthine oxidase is responsible for the oxidation of hypoxanthine to xanthine and xanthine to uric acid (Umamaheswari, 2009) and in the process, generates superoxide radicals and hydrogen 
peroxide. Therefore, inhibition of $\mathrm{XO}$ results in a decreased production of uric acid and superoxide.

Xanthine oxidase inhibitors are much useful, because they possess lesser side effects compared to uricosuric and anti-inflammatory agents. Allopurinol is the only clinically used inhibitor of XO (Kong, 2000) but it also exhibits side effects such as hypersensitivity syndrome and renal toxicity (Burke et al., 2006). Flavonoids and polyphenolic compounds have been reported to inhibit the activity of xanthine oxidase by blocking the production of superoxide radical and hydrogen peroxide (Meriem et al., 2010). The present study showed that $A$. obioense EtOAc and DCM fractions could be useful in inhibiting the progress of xanthine oxidase related diseases.

Allium cepa is a globally accepted genetic model for evaluating the genotoxic and mitosuppressive potentials of chemicals, drugs and herbal preparations (Namita and Somia, 2013). The results in tables 3 and 4 showed the genotoxicity effect of the EtOAc and DCM fractions of $A$. obioense on root tips of $A$. cepa.

Mitotic index (MI) is an indicator for measuring cells proliferative potential. It measures the number of cells undergoing mitosis and its inhibition could be considered as cellular death or a delay in cell proliferation (El-Shahaby et al., 2003).

In this study, the $A$. cepa roots treated with EtOAc and DCM fractions exhibited a significant decrease $(\mathrm{p}<0.05)$ in MI with increasing concentration (Tables 3 and 4). The MI at highest concentration of EtOAc and DCM fractions are 1.77 and 5.93 respectively.

The observed reduction in the MI by these fractions could be as a result of interference in the initiation of prophase; or the arrest of one or more mitotic phases (El-Shahaby et al., 2003). Sticky chromosomes (Plate 1 A- E) observed in the cells of the roots treated with $A$. obioense EtOAc and DCM fractions at higher concentrations could probably be as a result misfolding of chromosomal fibres. The misfolding of chromosomes resulted in the restriction of movements hence, cell death (Ping et al., 2012). Moreover, stickiness of chromosomes might also be attributed to DNA depolymerization, partial dissolution of nucleorotein, breakage and exchange of basic folded fibre units of chromatids and the stripping of protein covering of their DNA (Mercykutty and Stephen, 1980)

\section{CONCLUSION}

The study therefore concludes that $A$. obioense extracts possess strong anti-inflammatory property. However, genotoxic investigation suggested that the plant EtOAc and DCM fractions inhibit cell division of $A$. cepa at higher concentrations. Therefore, further in vivo study is recommended to identify the compounds responsible for the genotoxic effect so as to ensure safety in the use of the plant in orthodox medicine.

\section{REFERENCES}

Adedeji, O. A., Ayodele A. O., Elijah E. C., Olubunmi, A. F., 2012. Phytochemical screening of two tropical moss plants: Thidium gratum P. Beauv and Barbula indica Brid Grown in Southwestern Ecological Zone of Nigeria. American Journal of Analytical Chemistry, 3: 836-839.

Aina, O. I., Oyedapo, O. O., 2013. In vitro investigations into the antioxidant and anti-inflammatory potentials of the fractions and ethanolic extract of Cyclosorus afer (Christ.) Ching, stalks. Ife Journal of Science, 15 (2): 235-249.

Akinpelu, B. A., Makinde, A. M., Isa, M. A., Taiwo, P. A., Ojelabi, O. M., Oyedapo, O. O., 2015. In vitro evaluation of membrane stabilizing potential of selected bryophyte species. European Journal of Medicinal Plants. 6 (3): 181-190.

Bertram, G. K., 2004. Basic and clinical pharmacological. Lang medical book (9th Ed). McGraw-Hill Publishing Division; Chapters p 298-302; 36, 576-582.

Bhattacharya, S. 2011. Are we in the polyphenols era? Pharmacognosy Research, 3 (2): 147.

Burke, A., Smyth, E., FitzGerald, G. A. 2006. Analgesic-antipyretic agents: pharmacotherapy of gout. In: Brunton, L. L., Lazo, J. S., Parker, K. L. (Eds.). Goodman \& Gilman's The Pharmacological Basis of Therapeutics. 
New York: McGraw-Hill Medical Publishing Division; p. 706-10.

Edeoga, H. O., Eriata, D. O., 2001. Alkaloids, Tannin and Saponin Contents of Some Nigerian Medicinal Plants. Journal of Medicinal and Aromatic Plant Sciences, 23: 344-349.

El-Shahaby, O. A., Abdel-Migid, H. M., Soliman, M. I., Mashaly, I. A., 2003. Genotoxicity screening of industrial waste water using the Allium cepa chromosomes aberration assay. Pakistan Journal of Biological Science, 6(1): 23-28.

Farhad, M., Babak, A. M., Reza, Z. M., Hassan, R. M., Afshin, T., 2011. Response of proline, soluble sugars, photosynthetic pigments and antioxidant enzymes in potato (Solanum tuberosum L.) to different irrigation regimes in greenhouse condition. Australian Journal of Crop Science, 5:55-60.

Ferraz-Filha, Z. S., Vitolo, I. F., Fietto, L. G., Lombardi, J. A., Saude-Guimaraes, D. A., 2006. Xanthine oxidase inhibitory activity of Lychnophora species from Brazil ("Arnica"). Journal Ethnopharmacology, 107: 79-82.

Gupta, R. A., Dubois, R. N., 2001. Colorectal cancer prevention and treatment by inhibition of cyclooxygenase-2. Nature Reviews Cancer, 1:11-21.

Godwin, A., Akinpelu, B. A.,Makinde, A. M.,Aderogba, M. A. and Oyedapo, O. O., 2015. Identification of n-Hexane Fraction Constituents of Archidium obioense (Schimp. Ex Mull) Extract Using GC-MS Technique. British Journal of Pharmaceutical Research, 6(6):366-375.

Iwalewa, E. O., McGaw, L. J., Naidoo, V. Eloff, J. N., 2007. Inflammation: the foundation of diseases and disorders. A review of phytomedicines of South African origin used to treat pain and inflammatory conditions. African Journal of Biotechnology, 6(25): 2868-2885.

Jaykumar, V. D, Thomas, R., Kamat, S. D., Kamat, D. V., 2012.Comparative studies on in-vitro anti-inflammatory activity of Andrographis paniculata and Bacopa monnieri. Journal of Advanced Pharmaceutical Research, 2(1): 5- 8.

Konate, K., Souza, A., Thérèse, K. Y., Dibala, I. C.,
Barro, N., Millogo-Rasolodimby, J., Nacoulma O. G., 2011. Phytochemical composition, antioxidant and antiinflammatory potential of bioactive fractions from extracts of three medicinal plants traditionally used to treat liver diseases in Burkina Faso. International Journal of Phytomedicine, 3: 406-415.

Kong, L. D., 2000. Inhibition of xanthine oxidase by some Chinese medicinal plants used to treat gout. Journal of Ethnopharmacology, 73: 199-207.

Meriem, B., Karima, A., Dina, A., Djebbar, A., Mustapha, B., 2010. Kinetic Study on the Inhibition of Xanthine Oxidase by Extracts from Two Selected Algerian Plants Traditionally Used for the Treatment of Inflammatory Diseases. Journal of MedicinalFoods, 13 (4): 896-904.

Mercykutty, V. C. and Stephen, J., (1980). Andriatrycin induced gastric toxicity as demonstrated by the Allium cepa test. Cytologia, 45: $769-777$.

Mizushima, Y., Kobayashi, M., 1968. Interaction of anti-inflammatory drugs with serum proteins, especially with some biologically active proteins. Journal of Pharmacy and Pharmacology, 20: 169-173.

Namita, K., Somia, S., 2013. Allium cepa root chromosomal aberration assay: A review. Indian Journal of Pharmacentical and BiologicalResearch, 1(3): 105-119.

Oyedapo, O. O., Akinpelu, B. A., Akinwunmi, K. F., Adeyinka, M. O., Sipeolu, F. O., 2010. Red blood cell membrane stabilizing potentials of extracts of Lantana camara and its fractions. International Journal of Plant Physiology and Biochemistry, 2(4): 46-51.

Paudel, B., Bhattarai H. D., Kim, I. H., Lee,H., Sofronov, R., Ivanova,L., Poryadina,L., Yim, J. H., 2014. Estimation of antioxidant, antimicrobial activity and brine shrimp toxicity of plants collected from Oymyakon region of the Republic of Sakha (Yakutia), Russia. Biological Research, 47(1): 10

Ping, K.W., Darah, I., Yusuf, U.K., Yeng, C., Sasidharan, S., 2012. Genotoxicity of Euphorbia hirata: An Allium cepa assay. Molecules, 17: 7782-7791.

Rank, J., Nielson, M. H., 1993. A modified Allium 
test as a tool in the screening of the genotoxicity of complex mixture. Hereditas, 118: 49-53.

Rupesh, K. G., Sharma, S., Komal, S., 2013. Comparative evaluation of anti-arthritic activity of Pongamia pinnata (Linn.) Pierre and Punica granatum (Linn): an in-vitro study. International Journal of Pharmacy and Pharmacentical Sciences, 5(4): 721-724.

Samson, G., Nabere, O., Adama, H., Jeanne, F. M., Odile, G. N., 2011. Antioxidant, enzyme inhibition activities and polyphenol contents of three asteraceae species used in Burkina Faso traditionally medicine. International Journal of Pharmacy and PharmaceuticalSciences, 3 (5): 524-528.

Saso, L., Valentini, G., Casini, M. L Grippa E., Gaito, M. T., Leone, M. G. 2001. Inhibition of heat- induced denaturation of albumin by nonsteroidal antiinflammatory drugs (NSAIDs): Pharmacological implications. Archives of Pharmacal Research, 24: 150-158.

Savaroğlu, F., FilikIşçen, C., Öztopcu, A. P., Kabadere, S., Ilhan, S., Uyar, R., 2011. Determination of antimicrobial and antiproliferative activities of the aquatic moss Fontinalis antipyretica Hedw. Turkish Journal of Biology, 35:361-369.

Sofowora, A., 2006. Screening plants for bioactive agents, In: Medicinal Plants and Traditional Medicine in Africa. Third Edition, Spectrum Books Limited, Ibadan, Nigeria; p. 150-153.

Sweeney, A. P., Wyllie, S. G., Shalliker, R. A., Markham, J. L., 2001. Xanthine oxidase inhibitory activity of Selected Australian native plants. Journal of Ethnopharmacology, 75:273-277.

Trease, G., Evans, S. M., 2002. Pharmacognosy. 5th Edition, Bailer Tindal London; p. 2367.

Umamaheswari, M., 2009. In vitro xanthine oxidase inhibitory activity of the fractions of Erythrina stricta Roxb. Journal of Ethnopharmacology, 124: 646-648.

Umapathy, E., Ndebia, E. J., Meeme, A., Adam, B., Menziwa, P., Nkeh, C. B., Iputo, J. E., 2010. An experimental evaluation of Albuca setosa aqueous extract on membrane stabilization, protein denaturation and white blood cell migration during acute inflammation. Journal of Medicinal Plants Research, 4: 78995.

Vedpal, Santosh K. G., Gupta A. K., Dhirendra, P., Amit, G., 2013. Antiarthritic activity of Desmodium gangeticum root. International Research Journal of Pharmacy 4 (9): 100-103. 